\title{
Host plant range of Aphidophagous hoverflies in relation to their prey aphids in Badin, Sindh, Pakistan
}

Kamal Khan Abro*, Nasreen Memon, Attaullah Ansari and Muhammad
Ismail Memon

Department of Zoology, University of Sindh, Jamshoro-Pakistan

*Corresponding author's email: kamalgul143@gmail.com

Citation

Kamal Khan Abro, Nasreen Memon, Attaullah Ansari and Muhammad Ismail Memon. Host plant range of Aphidophagous hoverflies in relation to their prey aphids in Badin, Sindh, Pakistan. Pure and Applied Biology. Vol. 8, Issue 2, pp1228-1239. http://dx.doi.org/10.19045/bspab.2019.80065

\begin{tabular}{llll}
\hline \hline Received: 17/12/2018 & Revised: 16/04/2019 & Accepted: 18/04/2019 & Online First: 20/04/2019 \\
\hline \hline
\end{tabular}

\section{Abstract}

Aphidophagous hoverflies are one of the significant groups of family syrphidae for their larvae as well as adults, larvae feed on many insect pests i.e. aphids, jassids, thrips, which mainly infest several crops such as brassica, spinach, rice, wheat etc., whereas their adults are very important pollinators for these crops. This study was carried out to identify the hoverfly species which can be used as pest control of various agricultural crops grown in Badin which is a monsoon climatic region and main agricultural area of Sindh coastal line where a variety of flowering crops, fruits and vegetables are cultivated; and these include mango, banana, guava, lemon, jojoba, sugarcane, reddish, brassica, wheat, rice, okra, cabbage, chilli, cucumber, sunflower, tomato, onion etc. This study was conducted in the various farming fields of district Badin during the cropping season from January-April 2017. As a result a total of 253 specimens of 2 species, Sphaerophoria scripta and Episyrphus balteatus belonging to genus Sphaerophoria and Episyrphus were trapped by the help of insect hand net and malaise trap. Out of these 253 specimens, 34 were male and 219 were female. Pearson correlation analysis showed that there was strong positive and significant correlation of hoverflies population with the number of host plants as well as number of aphid colonies per month the values being $r=.820(p=0.012)$ and $r=.875(p=0.01)$ respectively.

Keywords: Aphidophagous hoverflies; Aphids; Badin; Host plants; Pakistan; Prey; Sindh

\section{Introduction}

Biological control and pollination are the significant ecosystem services conveyed by mostly flying insects for human beings. Syrphidae flies are also called hoverflies, flower flies fit to large family of small to a large species [1]. Hoverflies are a very essential group of insects because of their services to ecosystem are dual i.e., their larvae are chief natural danger to arthropods herbivores and their adults are good pollinators of several crops and wild plants [2]. Worldwide about 6000 species have been discovered [3]. Hoverflies provide essential ecosystem services as pollinators, biological control agent [4]. Economically the adult and larvae have economic important moreover adult suck the nectar and working as a pollinators agents where as their larvae feed on many crop insect pest such as aphids, 
Jassids, thrips which infest on many crops like brassica, spinach, rice, wheat so in this way they help in pest management [5]. Most of the hoverflies permit attention not only because of their remarkable diversity and economic importance, but also for their exposed behaviors and normally eyecatching presence [6]. The syrphidae flies are found in most parts of the Pakistan including in the especial areas where the fauna and flours is present for their nutrition and they have an ability to migrate from one place to another place when there is shortage of food or when condition is unfavorable for their survival and almost they can be found anywhere there is flowers are present [7]. The presence of hoverflies noticed on many different flowers and vegetables [8]. All adults mostly feed on pollen and nectar of flowering plants and the bloomy inclinations of these flies from species to species, some are highly generalized feeders and while others are extremely specialized feeders [9].This floral attractiveness may be due to different aspects i.e. shape and color of flowers, nectar and pollen accessibility [10] and also availability of prey and shelter [11].They also damage to aphid's population growth [12]. Most of the insects are relatively specific when they choosing their food material [1]. And it contains generalist predators show a hierarchy for many hosts [13]. Frequently adult needs amino acids and carbohydrates for egg production and energy [14].The selected flora are in around the fields to attract hoverflies adults in resulting to increase oviposition rates with fields and decrease the aphids' population [15]. The flowers play a very important role for their development, reproduction, growth and survival rate [16]. Some insect may be contingent on weeds for pollen and nectar [17]. It has been seen that in recent years, in agricultural fields, herbicides and pesticide use have reduced the plants diversity which may reduce the some natural enemies in biological control of insects pest, that's why some introducing flowering plants into ecosystem would be one of the good ways to increase pollen and nectar sources that regulate population, insects pests' and natural enemies [18]. About 49 hoverflies feed over peach aphid [19]. The altered species stole nectar, pollen or both nectar and pollen from a large variation of flowers \& also some species like Episyrphus balteatus and specific other aphidophagous species have been exposed pollen to be required for ovarian growth [20]. Aphid Schizapis gramimam $R$. is a severe pest having an inclusive host variety of at least 60 plants species including wheat, barley, sorghum and corn [21] and also observed that the 17 hoverflies species nourishing on 20 aphids species up on 14 species of main herbaceous plants[22]. Schizaphis graminum $R$. aphid are the serious pest having a wide host range of at least 60 plant species containing wheat, barley, sorghum and corn [23]. Aphids feed on the tissues of plant i.e. phloem and xylem [24]. They are severe pests of different ornamental plants, vegetables and field crops under order Homoptera and these are found on moderate, shady area more than 4000 species of aphids have been recorded worldwide which damage different plants, vegetables, ornamental plants and fruits by sucking cell sap [25]. Schizophis graminum aphids are the major pest having many host plant range of at least 60 plant species like wheat, barely, sorghum and corn [26]. They suck cell sap and inject toxic saliva into the plant body which results in bending of leaves presence of yellowed spots on greenery dimpling of fruit and appearance of buds [27]. The main objectives of this study were to observe the host plant range of syrphid fly species in various localities of Badin, to assess the most preferred plant species of syrphid flies under natural environment and to monitor the relationship between the 
abundance of syrphid flies and availability of host plants as well as aphid clusters.

Materials and methods

\section{Study area}

The study was conducted from January-April 2017 from different localities of Badin, Tando Bago, Matli and Talhar. Badin district is located in the south of Sindh Pakistan where the Indus River runs in south of the city. The district originates its name from its chief town, Badin. It is situated between $25^{\circ}$ $13^{\prime}$ and $26^{\circ} 12^{\prime}$ north latitudes and $67^{\circ} 22^{\prime}$ ' and $68^{\circ} 21^{\prime}$ ' east longitudes (Figure1).

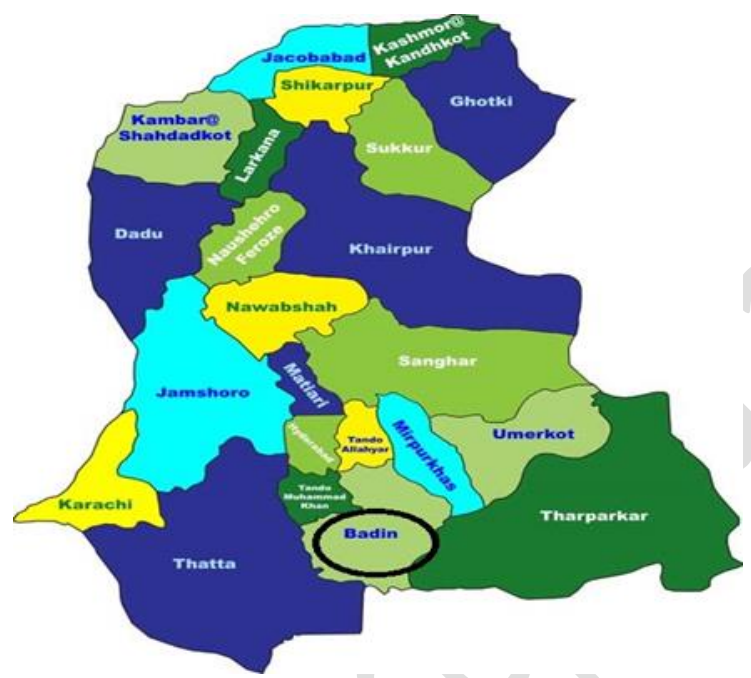

Figure 1. Map of Sindh showing Badin district

Sindh is most important agricultural province of Pakistan in which numbers of crops are cultivated, brassica, wheat, rice and different vegetables and fruits which are very important economically due to their yield or product from which we can and get different food product as well as use to export in order to increase economy of the country. Badin is a most significant component of the coastal ecosystem of Sindh, Pakistan. The climatic condition of the district is sub-tropical with cold winter and moderate summer. It is a muddy plain with fertile soil deposited by the flood management of the Indus River throughout thousands of years. Badin is irrigated mostly through the Sukkur and Kotri barrages system. Most of the land is cultivated and irrigated by canals or underground water. A variety of crops are grown in different peripheral areas in Badin, Sugarcane, rice, cotton, wheat and sunflower are main crops. The minor crops include tomatoes, chilies, pulses, onions and melons. The aphidophagous hover flies were collected randomly from various localities of Badin with the help of insect hand net and malaise trap. Malaise trap were often used for determining the composition of hoverflies communities from different crops. Each selected plot was of approximately $13 \times 9 \mathrm{~m}^{2}$ size and no insecticides were used. The space was $50 \mathrm{~cm}$ among the lines and plants. Experiment were carried out to monitor the month wise prevalence of Episurphus balteatus, Sphaerophoria scriptera and their interaction with their pray aphid.

We recorded all the available plant species which were highly attacked by the aphids which are general feeders as well as monophagous in nature. These crop pests are sap lovers and attack different crops like, brassica, chilli, onion, wheat, and rice as well 
on garden plants such as shrubs \& annual plants that were flowering during January to April. They can damage different body parts of these plants like stem, leaves and bud on which they enjoying their feeding and contaminated them resulting in wilting of these parts causing in low yield of these crops.

In natural environment we visited random study areas and measured only a one multi plant species were infested by aphids and randomly selected and each crop was noticed for 2 minutes. In this way there was a total of 25 minutes observation on each plant. Every plant, we calculated the quantity of staying individuals per aphidophagous hoverflies species by optical observation. Weekly survey of every blossoming crop was made from start to the end of its flowering stage. Once we started our observations $\left(2^{\text {nd }}\right.$ week of January, 2017) various crops were previously in bloom and similarly, at the conclusion of our study ( $3^{\text {rd }}$ week of April, 2017) some crops were still in blossoming condition.

\section{Data analysis}

The collected data were analysis using Pearson's correlation, following to observe the relationship between predators and theirs prays, using SPSS version 18.

\section{Results}

This study was carried out from January to April from district Badin Sindh Pakistan. District Badin is also acknowledged as a center of agriculture. In current Investigation a total of 253 specimen of two species Sphaerophoria scripta and Episyrphus balteatus of two genus Sphaerophoria, Episyrphus belonging to subfamily syrphinae were recorded from district Badin. Out of these 253 specimens, 198 were Episurphus balteatus while 55 were Sphaerophoria scripta. The population of female hoverflies of both species higher than male shown in (Table1). Episyrphus balteatus was recorded from brassica, cabbage, wheat, and tomato and green chili (Figure 2) while Sphaerophoria scripta was trapped from brassica, onion, okra, cauliflower, spinach and grasses (Figure 3). Moreover various aphid colonies of different species were also observed on these crops especially on Brassica, wheat, sunflower and lucerne, the host wise prevalence of Episurphus balteatus hoverflies and revealed that the maximum abundance of this species was found on Brassica followed by Sunflower while minimum on Cabbage (Figure 4). Whereas the most preferred host plant for Sphaerophoria scripta was Brassica followed by Lucerne while onion was the least preferred host plant (Figure 5). Month wise prevalence of Episyrphus balteatus revealed that the maximum (76) population were recorded in March followed by April (70) while minimum in January (22). Moreover these population dynamics of Sphaerophoria scripta showed that the maximum (23) populations of the species were recorded in April followed by March (22) while minimum in January (3) as shown in (Table 2) In addition to this we calculate the localities wise prevalence of aphidophagous hoverflies and found that the maximum $(55 \%)$ prevalence of these hoverflies was in Tando Bago followed by Matli (25\%) while minimum (20\%) prevalence were recorded in Talhar (Figure 6). Pearson correlation analysis revealed that there was strong positive correlation of hoverflies population with the number of host plant as well as number of aphid colonies per month the values being $\mathrm{r}=.920$ and $\mathrm{r}=.975$ respectively (Figure 7, $8 \&$ 9) and (Table 3). 


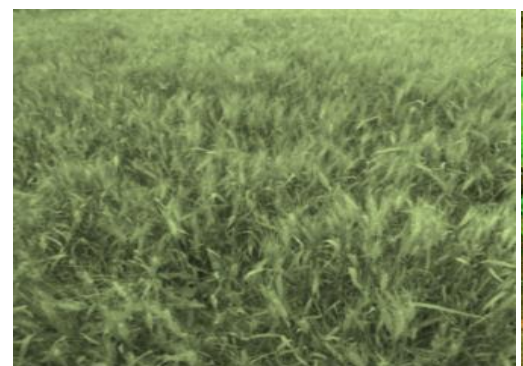

(Triticum aestivum)

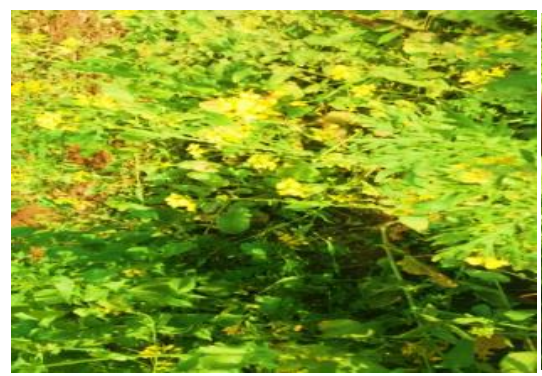

(Brassica compestris)

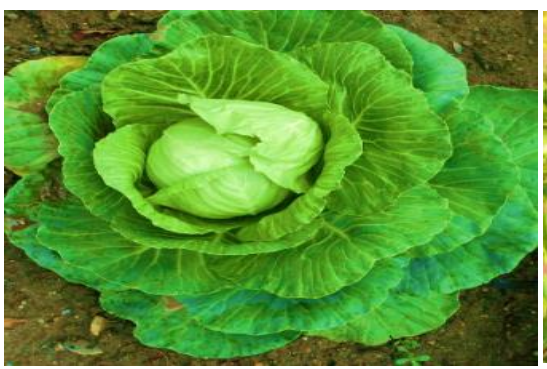

(Brassica oleracea)

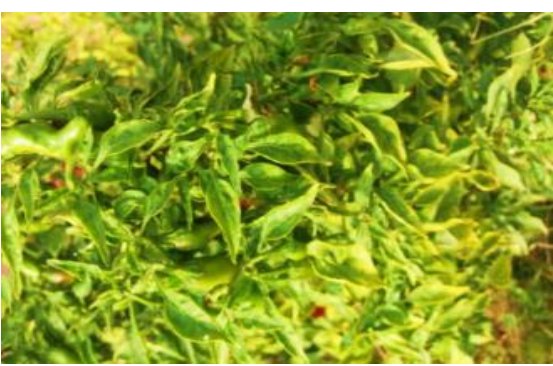

(Capsicum frutescens)

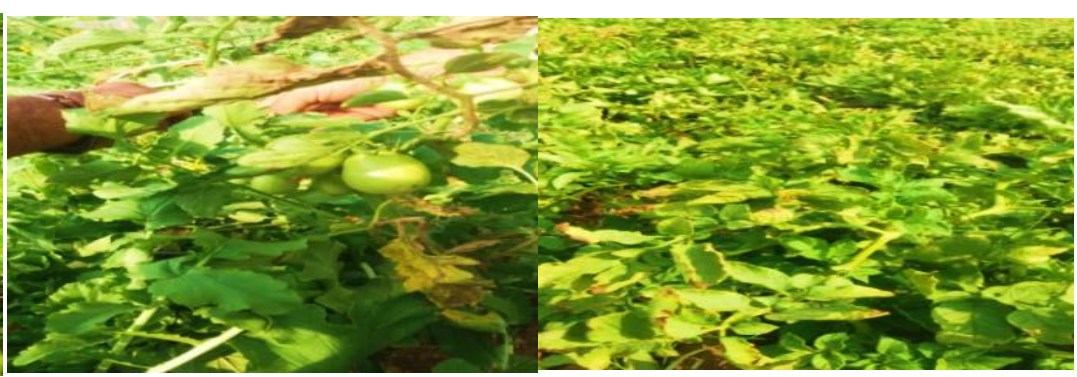

(Solanum lycopersicum)

(Solanum tuberosum)

Figure 2. Showing host plant of Episurphus balteatus

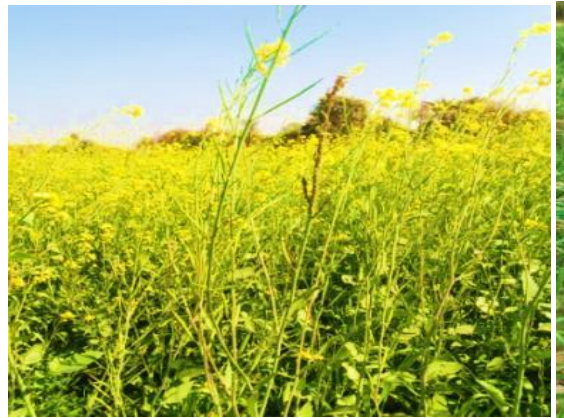

(Brassica campestris)

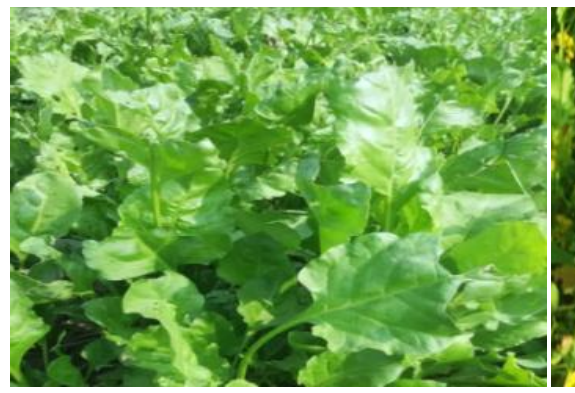

(Spinacia oleracea)

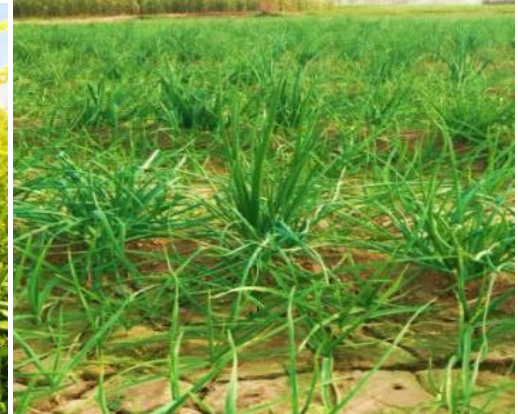

(Allium cepa)

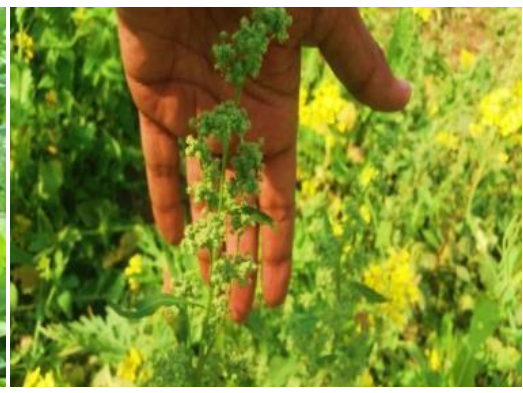

(Medicago sativa)

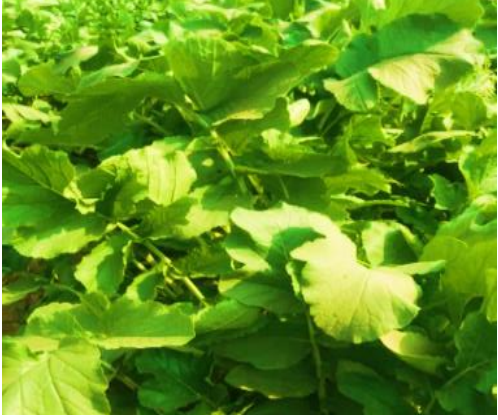

(Brassica oleracea)

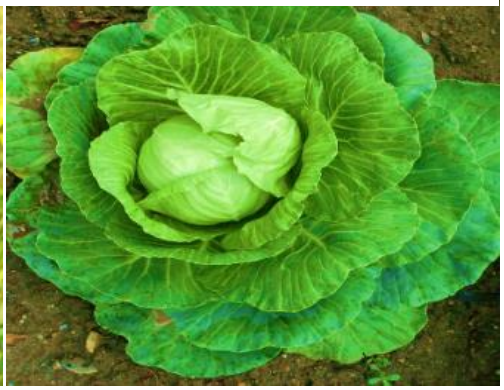

(Brassica oleracea)

Figure 3. Showing host plant of Sphaerophoria scripta 
Table 1. Showing the total number of male and female aphidophagous hoverflies and their host plants range

\begin{tabular}{|c|c|c|c|c|}
\hline Hoverflies & Host plant & Male & Female & Total \\
\hline Episyrphus balteatus & $\begin{array}{c}\text { Brassica, Potato, Sunflowers, Onion, } \\
\text { Okra, Wheat, Brinjal, cabbage, green chili }\end{array}$ & 32 & 166 & 198 \\
\hline Sphaerophoria scripta & $\begin{array}{c}\text { Brassica, Lucian, Onion, Okra, } \\
\text { cauliflower and spinach }\end{array}$ & 2 & 53 & 55 \\
\hline Total & & 34 & 219 & 253 \\
\hline
\end{tabular}

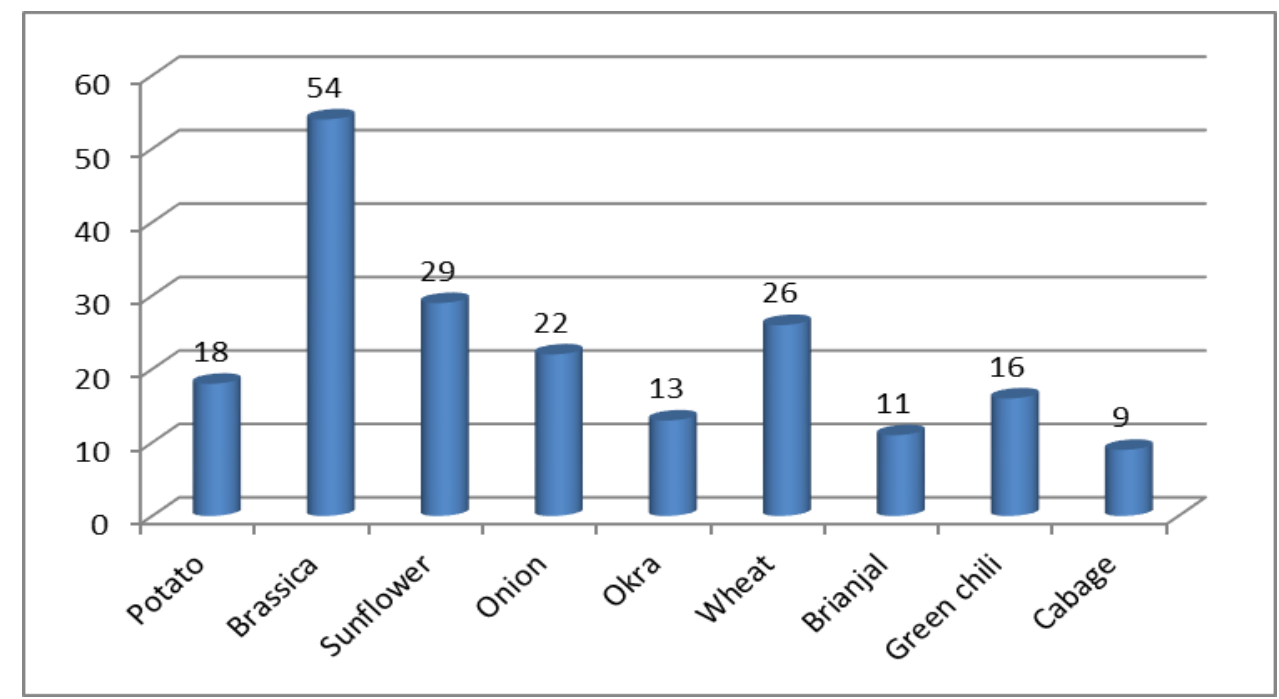

Figure 4. Host wise prevalence of Episyrphus balteatus hoverflies during Jan-April 2017

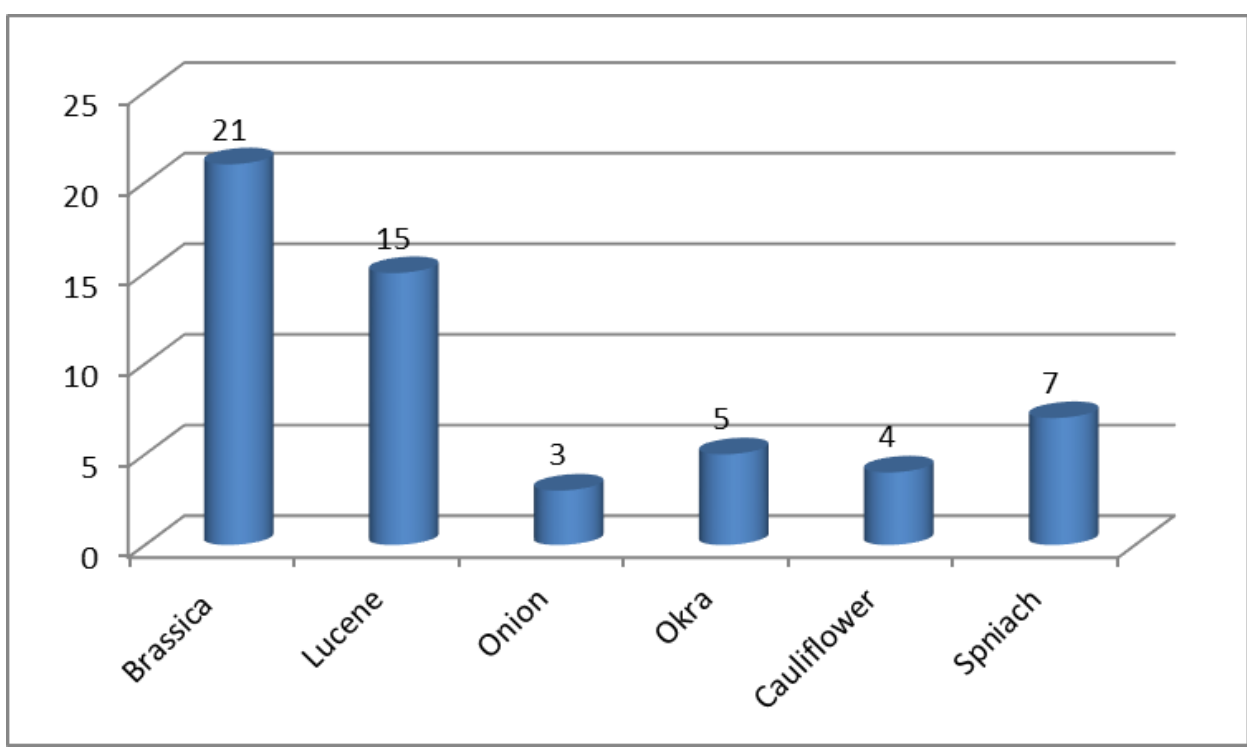

Figure 5. Host wise prevalence of Sphaerophoria scripta hoverflies during Jan-April 2017 
Table 2. Showing the monthly population of aphidophagous hoverflies

\begin{tabular}{|c|c|c|c|}
\hline Month & Total: No & S. scripta & E. balteatus \\
\hline January & 25 & 03 & 22 \\
\hline February & 37 & 07 & 30 \\
\hline March & 98 & 22 & 76 \\
\hline April & 93 & 23 & 70 \\
\hline Total & 253 & 55 & 198 \\
\hline
\end{tabular}

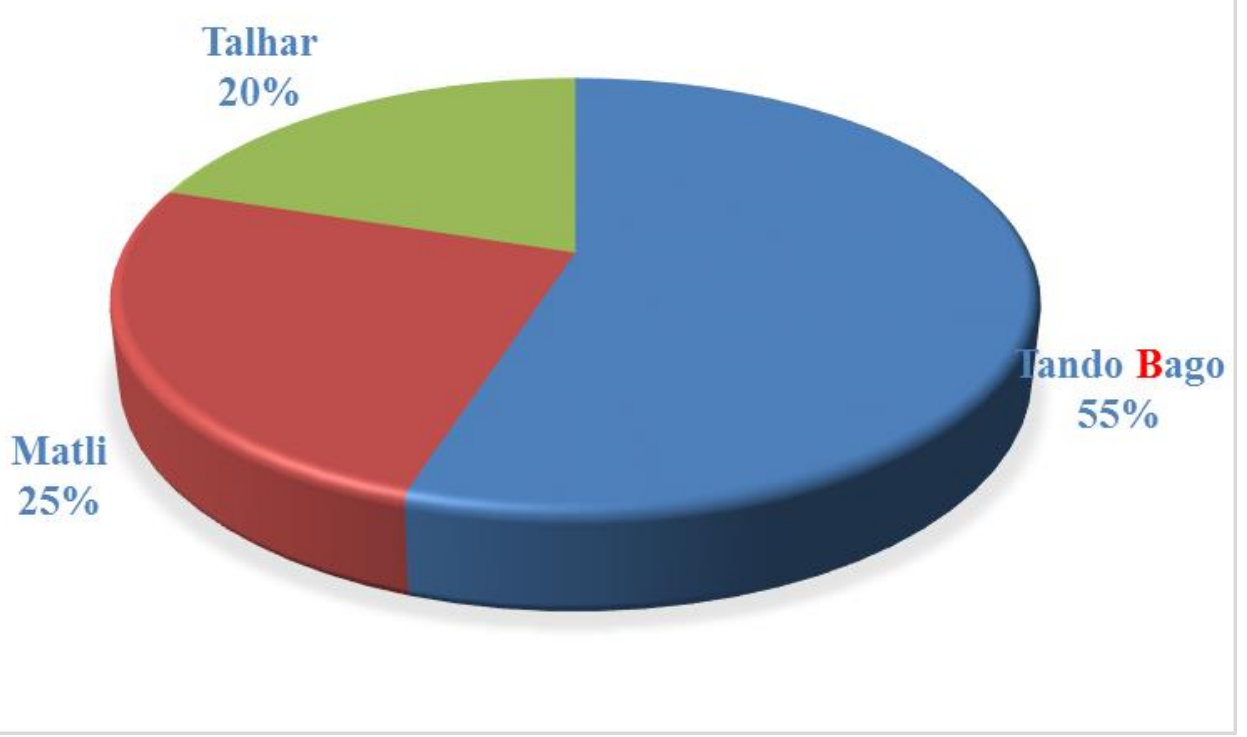

Figure 6. Locality wise prevalence percentage of hoverflies collected during January-April 2017

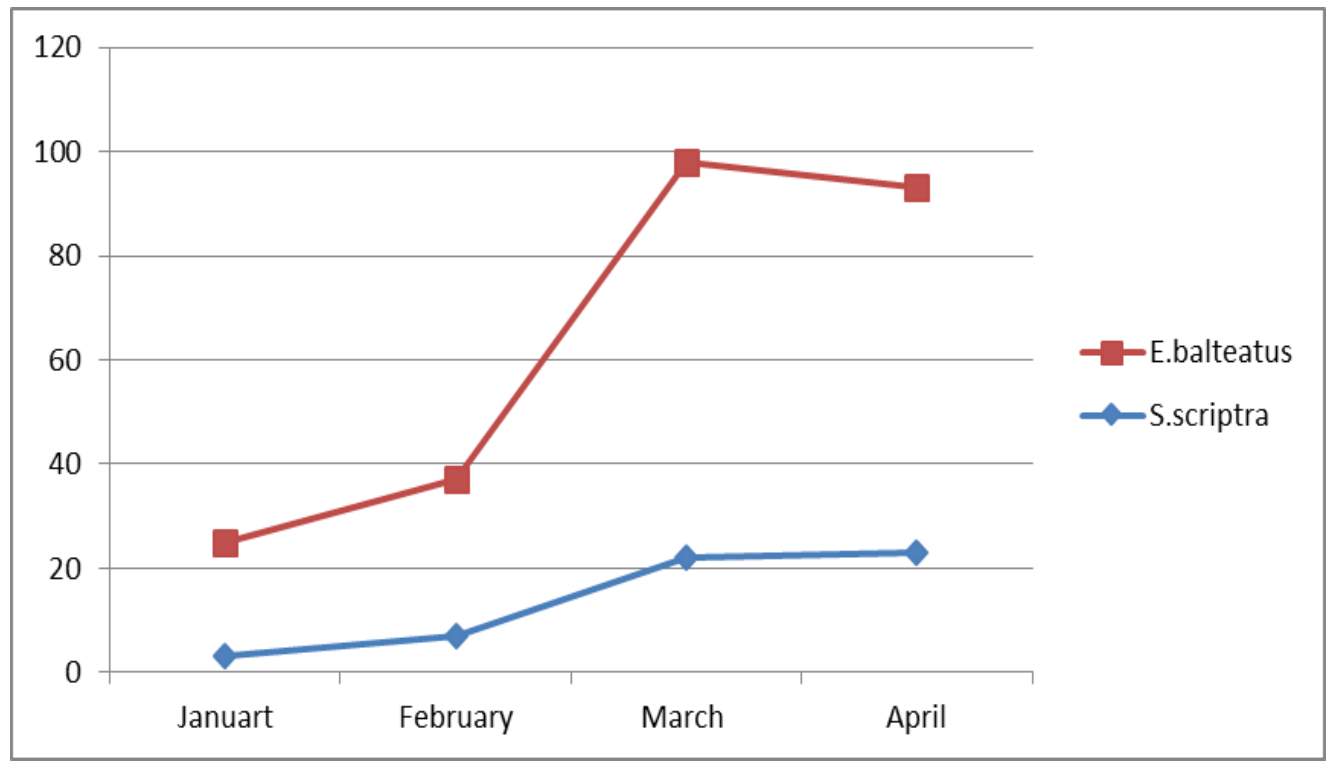

Figure 7. Month wise distribution of aphidophagous hoverflies in Badin 
Table 3. Showing the Pearson correlation value between the population of hoverflies, host plant and aphid colonies

\begin{tabular}{|c|c|c|c|c|}
\hline \multicolumn{5}{|c|}{ Correlations } \\
\hline \multirow{3}{*}{$\begin{array}{c}\text { Hoverfly pop } \\
\text { Noverfly pop }\end{array}$} & No of host & No of aphid colonies \\
\hline \multirow{3}{*}{$\begin{array}{c}\text { No of host } \\
\end{array}$} & Pearson Correlation & 1 & .920 & $.975^{*}$ \\
\cline { 2 - 5 } & Sig. (2-tailed) & & .080 & .025 \\
\cline { 2 - 5 } & Pearson Correlation & .920 & 4 & 4 \\
\cline { 2 - 5 } $\begin{array}{c}\text { No of aphid } \\
\text { colonies }\end{array}$ & Sig. (2-tailed) & .080 & 1 & $.953^{*}$ \\
\cline { 2 - 5 } & N & 4 & 4 & .047 \\
\cline { 2 - 5 } & Pearson Correlation & $.975^{*}$ & $.953^{*}$ & 4 \\
\cline { 2 - 5 } & Sig. (2-tailed) & .025 & .047 & 1 \\
\hline \multicolumn{2}{|c|}{$\mathrm{N}$} & 4 & 4 & 4 \\
\hline
\end{tabular}

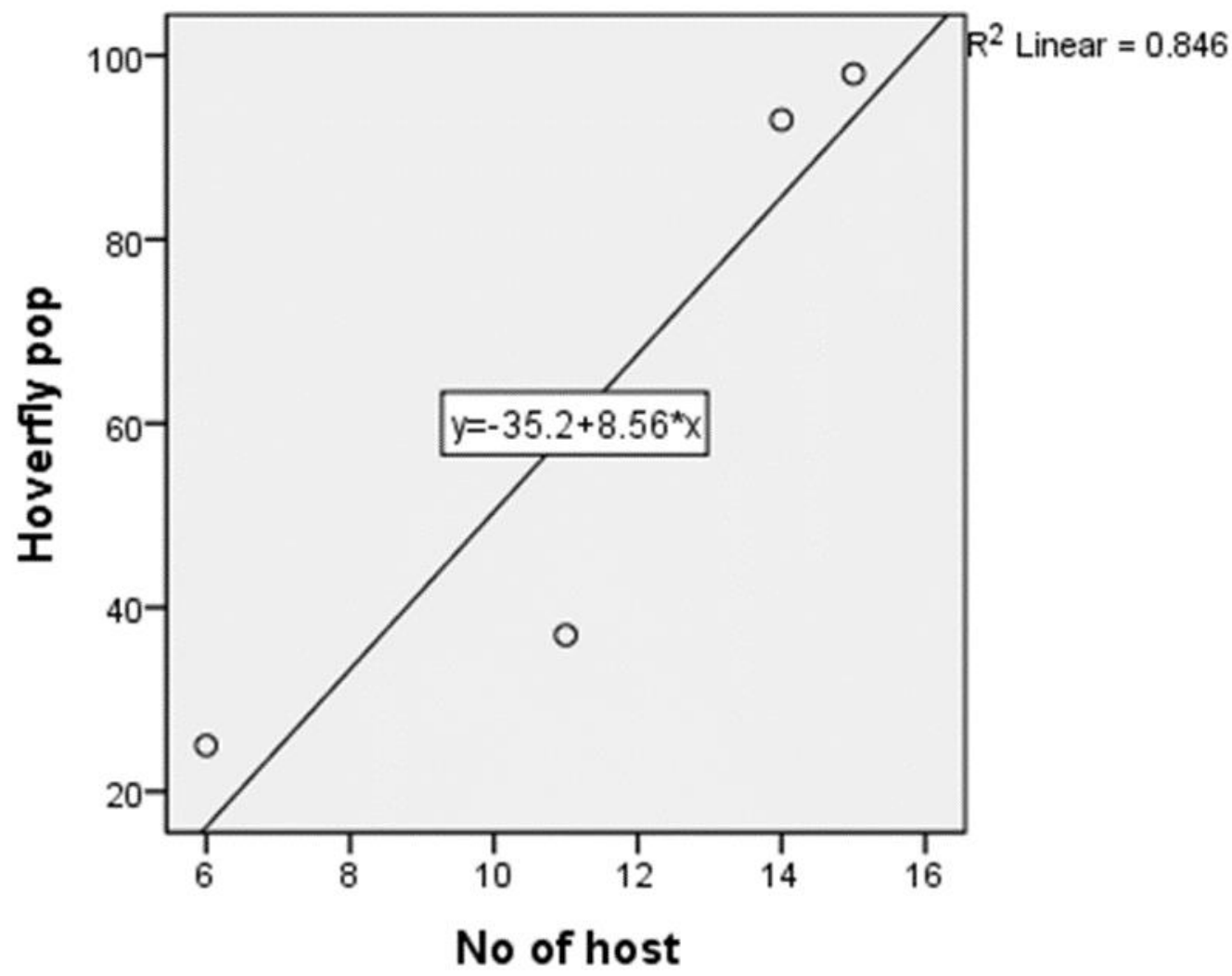

Figure 8. Showing the strong positive correlation of aphidophagous hoverflies with their host plant 


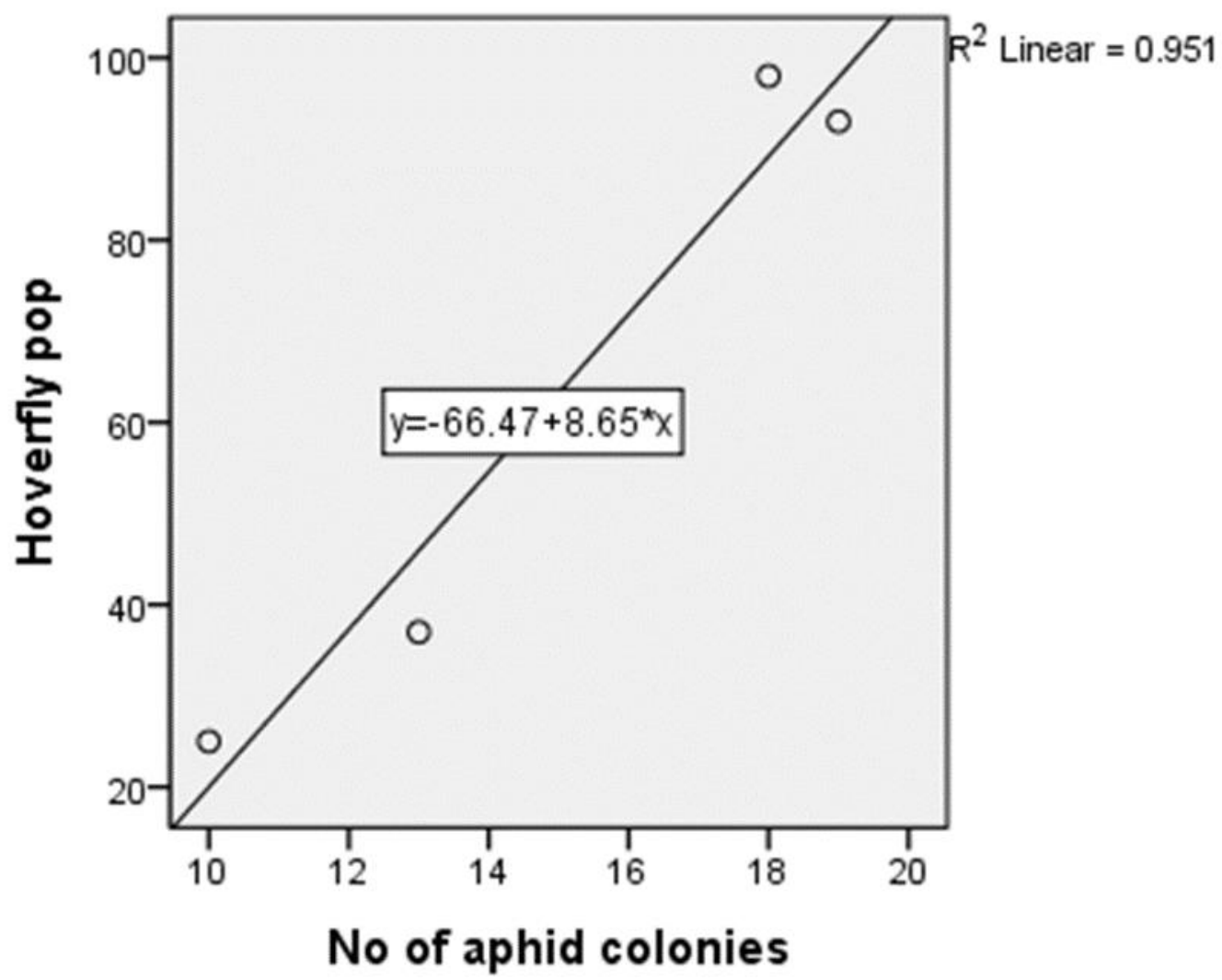

Figure 9. Showing the strong positive correlation of aphidophagous hoverflies with aphid colonies

\section{Discussion}

Usually the aphidophagous syrphid flies species are attracted toward the actinomorphic flowering plants. These flies were mostly observed in or near aphid colonies and in current investigation we observed that whenever any aphid colony was observed one or more larvae and adult was recoded beside that colony and we discovered that the host plants play very important role in distribution and range of egg laying period of aphidophagous hoverflies. [30] Also had similar observations that aphidophagous hover flies did not oviposit on clear vegetables, plants and crops, instead they found to lay their eggs on or near thick aphid colonies. The findings of this research are in acquiescence with that result of [31] that in their experimental study proved that there is positive correlation between predator and no of aphid colonies. During field survey of different localities of Badin it was noticed that these flies mostly prefer infested plants that having huge camps of aphids. According to [32] the abundance of aphidophagous hoverflies at a specific time in particular environment profoundly relies on availability of certain type of host plants, flowers, as well as food for both adult and larvae to accomplish their feeding requirement. Throughout study period, we also found that Badin is a very important district from agriculture point of view as number of crops, vegetables and fruits are grown here on large scale which include wheat, Brassica, onion, lady finger, cauliflower, spinach, chilies, tomato and grasses and found vast number of aphid 
colonies were observed on these crops, brassica and chili crops and host Plant range of aphidophagous hover flies from Badin.

The current study Episyrphus balteatus was found most prevalent having total number of 198 specimens while Sphaerophoria scripta was found to be least prevalent specie having only 55 specimens. Observations of [33-35] were also more or less similar they also found Episyrphus balteatus as the most abundant species during their study. Most hoverflies were recorded from Brassica campestris crop because a vast number of aphid colonies were observed on brassica and it is found to be most favorable host plant for both hoverfly species from Badin, Sindh, Pakistan. While during surveying for the aphidophagous hoverflies host plant range and availability of larval host infested host plant during JanuaryApril in and everywhere from Badin district, total 252 aphidophagous hoverflies were recorded during study period. Most of the study of host plant range of aphidophagous hoverfly species has been done on some of agricultural and non-agricultural plants. It is assessed that the relative attractiveness of hoverflies was on many plants. The interaction of hoverfly species with environmental factors (temperature, humidity, rainfall etc.) generally varied with geographical dissemination. [36] reported a positive correlation between temperature and number of aphidophagous syrphid in tropical areas of the world, whereas in subtropical areas of the world including Pakistan, the negative correlation of temperature with abundance of hoverflies was observed [37]. In this study also the maximum numbers of hoverflies were recorded in March and April (spring season), the reason for this population increase in these months was due to the favorable tropical climatic condition and also presence of huge number of aphid's thick grapes like colonies on infested crops and availability of more quantity of host plant for larvae and vegetation shelter of herbs, shrubs and trees for the nectar of adult flies.

\section{Conclusion}

Present study concluded that both biotic factors play a vital role in abundance and distribution of hoverflies, this indicates that larval diet and flowering plants play very important role in shaping population dynamics of aphidophagous hoverflies.

\section{Authors' contributions}

Conceived and designed the experiments: $\mathrm{N}$ Memon, Performed the experiments: KK Abro, Analyzed the data: A Ansari, Contributed materials/ analysis/ tools: MI Memon, Wrote the paper: KK Abro.

\section{Acknowledgement}

This study is part of Higher Education Commission Islamabad Pakistan funded project No: 203838/NRPU/R\&D/HEC/14

\section{References}

1. Potts SGT, Petanidou S, Roberts CO, Toole A, Hulbert \& Willemer P (2006). Plant- Conservation 129: 519-529.

2. Tooker JFH Hauser \& Hanks LM (2006). Floral host plants of Syrphidae and Tachinidae (Diptera) of Central Illinois. Ann Entomol Soc Am 99(1): 96112.

3. Miranda GFG, Young AD, Locke MM, Marshall SA, Skevington JH \& Thompson FC (2013). Key to the genera of Nearctic Syrphidae. Canadian $J$ of Arthropod Identi 23: 1-351.

4. Kevan PG (1999). Pollinators as bioindicators of the state of the environment: species,activity and diversity. Agri, Ecosys and Environ 74: 373-393.

5. Wnuk A (1972). Investigations on the species composition of predaceous Syrphidae (Diptera) occurring in the colonies of aphids on fruit trees and shrubs. (in Polish, English abstr). Pol Pis Entomol 42: 235-247.

6. Miranda GFG, Young AD, Locke MM, Marshall SA, Skevington JH \& 
Thompson FC (2013). Key to the genera of Nearctic Syrphidae. Canadian $J$ of Arthropod Identi 23: 1-351.

7. Kenji OharaTokushima Prefectural Museum Bunkanomori Park Tokushima (770-8070), Japan (Email: ohara@staff.comet.go.jp).

8. Drabble E \& Drabble H (1927). Some flowers and their dipteran visitors. New Phytologist 26: 115-123.

9. Haslett JR (1989). Adult feeding by holometabolous insects: pollen and nectar as complementary nutrient sources for Rhingiacampestris (Diptera: Syrphidae). Oecologia 81: 361-363.

10. Sutherland JP, Sullivan AS \& Poppy GM (1999). The influence of floral character on the foraging behaviour of the hoverfly Episyrphusbalteatus. Entomolgia Experimentalis et Apllicata 93: 157-164.

11. Colley MR \&Luna JM (2000). Relative attractiveness of potential beneficial insectary plants to aphidophagous hoverfies (Diptera: Syrphidae). Environ Entomol 29: 1054-1059.

12. Chambers RJ \& Adams THL (1986). Quantification of the impact of hoverflies (Diptera: Syrphidae) on cereal aphids in winter wheat: an analysis of field populations. J Appl Ecol 23: 895904.

13. Fabricius JC (1805). "Systemaantliatorumsecundumordines, genera, species.373 pp + 30 pp" Brunsvigae (Brunswick).

14. Sadeghi H \& Gilbert F (1999). Individual variation in oviposition preference, and its interaction with larval performance in an insect predator. Oecologia Berlin (118): 405-411.

15. Gilbert FS (1993).Hover flies. Naturalist's Handbook No.5. Richmond Pub. Sloughs England.

16. Ambrosino MD, Luna JM, Jepson PC \& Wratten SD (2006). Relative frequencies of visits to selected insectary Plants by
Predatory Hoverflies (Diptera: Syrphidae), Other Beneficial Insects and Herbivors. J Environ Entomol 35(2): 394-400.

17. Jervis MA, Kidd NAC,Fitton MG,Huddleston T \&Dawah HA (1993). Flowervisiting by hymenopteran parasitoids. J. Nat. Hist. 27, 67-106.

18. Landis DA, Wratten SD\& Gurr GM (2000). Habitat management to conserve natural enemies of arthropod pests in agriculture.

19. Marshall J, Mc Namara J \&Houston A (2010). The state of Darwinian theory. Behav Ecol Sociobiol. doi:10.1007/s00265-010-1121-y

Maynard-Smith J (1964) Group selection and kin selection. Nat 201:1145-1147.

20. White AJ,Wratten SD, Berry NA \& Weigmann U (1995). Habitat manipulation to enhance biological control of brassica pests by hover flies (Diptera: Syrphidae). J Econ Entomol 88: 1171-1176.

21. Van Emden HF, Eastop VF, Hughes RD \&Way MJ (1969). The ecology of Myzusperisica. Ann Rev of Entomol14:197-270.

22. Gilbert FS (1981). Foraging ecology of hover flies (Diptera: Syrphidae): morphology of the mouthparts in relation to feeding on nectar and pollen in some common urban species. Ecol Entomol 6: 245-62.

23. Kloen H \&Altieri M (1990). Effect of mustard (Brassica hirta) as a non- Crop plant on competition and insect pests in broccoli. Crop Protection 9: 90-96.

24. Masayuki MT (1997). Ecology of hoverflies in Meditarians. Ecol Res 12: 239-248.

25. Kindler SD \& SM Spomer (1986). Biotypic status of six greenbug (Homoptera: Aphididae) isolates. Environ Entomol J 15: 567-572. 
26. Spiller NJ,Koenders L\&Tjallingii WF (1990). Xylem ingestion by aphids-a strategy for maintaining water balance. Entomol Exp Appl 55: 101-104.

27. Lund T,Sæthre MG,Nyborg I,Coulibaly O \&Rahman MH (2010). Farmer field school-IPM.

28. Bowling SA, Clarke JD, Liu Y Kl \& DF Dong X (1997). The cpr5 mutant of Arabidopsis expresses both NPR1dependent and NPR1-independent resistance. Plant Cell 9: 1573-1584.

29. Hashmi AA (1994). Insect Pest Management, cereal and cash crops. National Agric. Res. Center, Islamabad, pp 317.

30. Pineda S, Rojo PM, Sjdro C, Perez BN \& Marcos MA (1997). A Revision of the hoverflies (Diptera: Syrphidae) from the Azores archipelago with notes on Macaronesiansyrphid fauna. Archipelago. Life and Marine Sci 15: 6582.

31. Bilashini YTK and Singh. RK (2007). Biological control potential of Coccinella Septumpunctata (Linnacus) (Coleoptera: coccinellidae) on major homopteran pests ofrapeseed. J Biol Control 2: 157-162.

32. Potts SG, Vulliamy B \& Willmer P (2003). Linking bees and flowers:how do floral communities structure pollinator communities. Ecol 84: 2628.

33. Ghahari HR., Hayat M, Tabari \& Ostovan H (2008). Hover Flies (Diptera: Syrphidae) From Rice Fields and Around Grasslands of Northern Iran. Munis Entomol Zool 3(1): 275-284.

34. Ghorpade K (2015). Hover-flies (Diptera: Syrphidae) in the Bombay Natural History Society Collection, with an annotated checklist of those recorded from Maharashtra, India. $J$ of the Bombay Nat Hist Soc (JBNHS) 112(2): 106-110.

35. Gilbert F S (1981). Foraging ecology of hoverflies: morphology of the mouthparts in relation to feeding on nectar and pollen in some common urban species. Ecol Entomol 6(3): 245-262.

36. Carvalho AMC, Mendes J, Marghiori CH. \&Lomônaco C (1991). Variaçãoespacial esazonal de dipterous muscóidesemduasáreasdecerrado no município de Uberlândia-MG. Calliphoridae e Muscidae. R. Cent. Ci. Bioméd Univ Fed Uberlândia 7: 27-34.

37. Sajjad A, Saeed S \& Ashfaq M (2010). Seasonal Variation In abundance and composition of Hoverfly (Diptera: Syrphidae) communities in Multan, Pakistan. Pak J Zool 42(2): 105. 